Maja Šabec

Universidad de Ljubljana

\title{
BARTOLOMÉ DE TORRES NAHARRO ENTRE LA PRECEPTIVA Y LA PRODUCCIÓN DRAMÁTICAS
}

\section{Introducción}

Hasta el siglo XV la literatura castellana no conoce una verdadera terminología dramática. Para sus creaciones en distintos géneros los autores utilizaban términos imprecisos e inconsecuentes. En el siglo XV surgieron los primeros »comentarios « dramáticos, reducidos a breves notas, partes de poemas o introducciones a otras obras literarias. El primer intento de definir los términos del teatro clásico - la comedia y la tragedia - en latín vulgar data del año 1438 o 1439: el poeta Juan de Mena (1411-1456) escribió en el Segundo preámbulo a la Coronación que los poetas escriben en tres estilos - »tragédico, satírico o comédico«; el primero se utiliza en la escritura »que habla de altos hechos y por bravo y soberbio y alto estilo«, comienza »en altos principios « y acaba »en tristes y desastrosos fines «; y en cuanto al tercer estilo dice: »El tercero estilo es comedia, la cual trata de cosas bajas y pequeñas y por bajo y homilde estilo, y comienza en tristes principios y fenece en alegres fines, del cual usó Terencio. « ${ }^{1}$ La referencia a Terencio es significativa, porque la teoría dramática española se formó en estrecha relación con las interpretaciones de los comentaristas de Plauto y Terencio. En la definición de la comedia de Mena hay dos elementos importantes: la bajeza de las cosas tratadas y el estilo humilde, por un lado, y el final alegre, por el otro. Cincuenta años más tarde, Hernán Núñez en su Glosa sobre las trescientas del famoso poeta Juan de Mena, al explicar la copla 123. dijo: »La comedia es, según los griegos, una comprehensión del estado civil y privado sin peligro de vida, y según la sentencia de Tulio, la comedia es imitación de la vida, espejo de las costumbres, imagen de la verdad «. ${ }^{2}$ Iñigo López de Mendoza - Marqués de Santillana tiene puntos de vista parecidos a los de Juan de Mena, por beber ambos en fuentes comunes, en sentido extenso. En su dedicatoria a la Comedieta de Ponza (1444) declara: »Comedia es dicha aquella cuyos comienzos son trabajosos, e después el medio e fin de sus días alegre, gozoso y bien aventurado. $\ll^{3}$ Todas estas definiciones se nutren de la herencia clásica y todas tienen en común la preocupación de distinguir la comedia de la tragedia. Destacan dos notas: la inferioridad de la comedia respecto a la tragedia y el distinto »tono« - alegre - de la comedia. Poco a poco el primer aspecto se fue borrando, y en el Siglo de Oro los preceptos dramáticos se centraron casi exclusivamente en el segundo. Conviene aquí mencionar la formulación original del término »tragicomedia que Fernando de Rojas incorporó en su Prólogo a la Celestina: »Otros han litigado sobre el nombre que no se había de llamar comedia, pues acaba en tristeza, sino que se llamase

\footnotetext{
${ }^{1}$ Sánchez Escribano, Federico, y Porqueras Mayo, Alberto, Preceptiva dramática española del Renacimiento al Barroco, Gredos, Madrid, 1965, p. 53.

2 Ibid., p. 15.

${ }^{3}$ Ibid., p. 54.
} 
tragedia. El primer autor quiso dar denominación del principio, que fue placer, y llamóla comedia: yo viendo estas discordias entre estos extremos, partí ahora por medio la porfía y llaméla tragicomedia. $\aleph^{4}$

Avanzado el siglo XV nace en el territorio español la primera generación de autores dramáticos, los así llamados primitivos. La dramática de estos escritores desciende de la tradición medieval profana y religiosa y - salvo raras brillantes excepciones - resulta insípida y mal construida. Sin embargo, aunque no haya dejado huellas de mayor interés, a lo largo de los cuarenta años entre los siglos XV y XVI ha creado, con ejercicio de renovación y búsqueda de nuevas vías de dramatización, la base de la rica y compleja dramática española que culminó un siglo más tarde.

\section{Bartolomé de Torres Naharro}

El panorama de los representantes más importantes de dicha generación (Juan del Encina, Lucas Fernández, Fernando de Rojas y Gil Vicente) abarca también a Bartolomé de Torres Naharro (1485?-1520?). Sin alcanzar madurez constructiva en sus comedias, que por lo general manifiestan un desequilibrio escénico similar al de sus contemporáneos, ocupa un lugar fundamental en la historia de las letras castellanas por ser el primero en formular un modelo sistemático según el cual las componía. Torres Naharro tomó su »profesión « de escritor teatral da una manera muy responsable y crítica. Reflexionó sobre la esencia del arte dramático y trató de explicarse las leyes y los principios de su trabajo, situándose así entre los primeros autores que sintieron la necesidad de unir los aspectos tanto teóricos como prácticos de su creación. Con sus especulaciones - aunque un tanto abstractas y generalizadoras - sobre la teoría dramática se adelantó más de medio siglo a nombres tan ilustres como Juan de la Cueva o Lope de Vega, y, desde el punto de vista metódico, hasta los superó. El valor de su aportación es, por lo tanto, sobre todo histórico.

Los datos biográficos de Bartolomé de Torres Naharro son relativamente escasos. Casi todo lo que se sabe de su persona figura en dos cartas acompañando la primera edición de su obra más importante, Propalladia (1517): en la carta de recomendación escrita por un misterioso amigo suyo, literato francés que vivía en Nápoles, Mesinierus. I. Barberius Aurelianensis, al famoso humanista e impresor parisiense de origen belga, Jodocus Badius Ascensius (Josse Badio Ascensio) ${ }^{5}$, y en el permiso del papa León X de imprimir el libro. Se entiende que el dramaturgo nació hacia 1485 en Extremadura, en la localidad Torre Miguel Sexmero, de la que adoptó parte de su nombre. Debió de estudiar

${ }^{4}$ Rojas, Fernando de, La Celestina, Cátedra, Madrid, 2000, p. 81.

5 No está comprobado que se trate de una carta en el sentido estricto de la palabra. Joseph E. Gillet, Propalladia and other works of Bartolomé de Torres Naharro, Bryn Mawr-Philadelphia, University of Pennsylvania, 1943-1951, vol. 3, p. 39, afirma que Mesinierus I. Barberius y Badius sin duda fueron amigos y que cooperaron en varias ocasiones en la publicación de los libros. Quizá en este caso la intención de Barberius fue en realidad enviar el manuscrito de Badius a París para que lo imprimiera (junto con la carta), y, cuando abandonó este proyecto y entró en contacto (o bien lo hizo el mismo Naharro) con el impresor local Jean Pasquet, la carta fue imprimida en Propalladia como epístola introductoria presentando un nuevo autor, no solamente al impresor Badius, sino al público en general. Gillet propone también otra hipótesis: que Barberius nunca hubiera pensado en mandar el manuscrito a París y que dicha carta no fuera sino un medio "publicitario « para introducir en el libro un nombre famoso. 
en la universidad de Salamanca, pero no se sabe si obtuvo título alguno. Más tarde tuvo que ser ordenado de sacerdote, probablemente en su diócesis natal, ya que el privilegio papal hace alusión al autor como »clericus Pacensis diocesis $\ll^{6}$. A principios del siglo XVI debió de colgar los hábitos y se alistó en el ejército real y con él recorrió Andalucía y Valencia, y después de una serie de aventuras - entre otro habría sido capturado por los piratas moros - llegó finalmente a Roma, donde entró al servicio de los altos dignatarios eclesiásticos. En 1516 sirvió al cardenal Bernardino de Carvajal, y el año siguiente apareció en Nápoles, en casa del Marqués de Pescara, Fernando Francisco de Avalos (o Dávalos), al que dedicó la Propalladia. En los años de su vida más o menos trabajosa en los palacios señoriales italianos se representaron varias de sus obras, algunas incluso en la corte pontifical. Después de la publicación del libro, su vida »cortesana« fue interrumpida, tal vez debido a la sátira en sus comedias o a su espíritu aventurero. No se conoce con certeza la fecha de su muerte, unos sugieren el año 1520 o 1524, otros 1530.

A pesar de que el dramaturgo extremeño desarrolló su actividad dramática en Italia, estando por lo tanto familiarizado con el teatro italiano, éste no dejó profundas huellas en su producción. Se han señalado algunos motivos, como la forma de titular las comedias a partir del nombre del protagonista, aunque en esto el propio autor dice seguir a Plauto. ${ }^{7}$ Más que la práctica teatral italiana que se empeñó en imitar y transponer en nuevas situaciones la comedia clásica, hubo de producir en él un fuerte impacto la atmósfera bulliciosa del momento, ya que llegó a Roma en el momento en que el pensamiento y el arte renacentistas estuvieron en su pleno auge. De allí absorbió la preocupación teórica por el teatro, igual que los autores medievales italianos, Tasso, Giraldi y Speroni, preocupados por justificar y fundamentar en la preceptiva su creación literaria. Asimismo conoció algunos tratados clásicos sobre el arte literario, aunque más que en ellos se inspiró en los humanistas de su época, sobre todo, como veremos más adelante, en el ya mencionado belga Josse Badio. Al redactar su exposición teórica Naharro se alejó de los famosos modelos aristotélicos, o, aún mejor, ni siquiera los tomó en consideración, aunque parece muy poco probable que no los conociera, ya que la traducción latina de la Poética de Valla del año 1498 fue muy divulgada entre los escritores italianos renacentistas. ${ }^{8}$

\section{Propalladia}

Las obras literarias de Torres Naharro conservadas en forma impresa son el Diálogo del Nacimiento (su única aportación al teatro religioso) y ocho comedias: Serafina, Trofea, Soldadesca, Tinelaria, Himenea, Jacinta, Calamita y Aquilana. Algunas se imprimieron en ediciones sueltas, mientras que el Diálogo y las seis primeras comedias

\footnotetext{
${ }^{6}$ Leo papa X, en Gillet, op. cit., vol. 1, p. 146.

${ }^{7}$ Pérez Priego, Miguel Angel, Estudios sobre teatro del Renacimiento, Universidad Nacional de Educación a Distancia, Madrid, 1998, p. 52, nota 3.

${ }^{8}$ Conviene señalar que a pesar de la mencionada traducción y otras ediciones que siguieron a ésta, en la primera mitad del siglo XVI no hubo valiente alguno que se animara a enfrentarse con el comentario de esta obra de Arisóteles; por regla general, prefirieron emprender sus propios caminos o apoyarse en Platón u Horacio. Sólo después del ejemplo de Robortello (1548) se publicaron muchos otros comentarios, escritos cada vez más frecuentemente en lengua vernácula. La primera "poética" en castellano, Filosofia Antigua poética de Alonso López Pinciano, se publić sólo en 1596 en Valladolid.
} 
se publicaron, con algunas otras composiciones más cortas (capitulos, epístolas ...), en 1517 en Nápoles bajo el título común de Prolalladia. En la edición ulterior (Sevilla 1520) el autor añadió dos comedias más, la Calamita y la Aquilana. El éxito innegable del libro está confirmado por un número considerable de reimpresiones, nueve en cincuenta años. En la primera mitad del siglo esta obra no molestó a nadie, sin embargo, después de la reacción católica de la segunda mitad del siglo, que culminó con el concilio de Trento, ya no fue así. Cuando en 1559 se publicó el Index librorum prohibitorum de Pablo IV, el inquisidor español, Fernando de Valdés, no tardó en poner en circulación el suyo, incluyendo también Propalladia. Pero a pesar de la condenación que duró durante trece años, corrieron por la península ibérica ejemplares del libro impresos en el extranjero, en Italia, Alemania y en Flandes. En 1572 la Inquisición levantó la proscripción y es cuando volvió a publicarse en Madrid una nueva - y a la vez la última - edición. No hay duda alguna de que la obra naharresca fue conocida en España, pero es muy probable que sólo fuera leída y no representada, puesto que no la mencionan, entre las obras representadas de sus predecesores, ni Cervantes en el Prólogo a Ocho comedias y entremeses (1615), ni Agustín de Rojas en el Viaje Entretenido (1603). Lope de Vega sí citó una vez a Naharro, y lo imitó varias. ${ }^{9}$

El autor explica el título Propalladia en el prefacio (Prohemio ${ }^{10}$ ) del libro: »Intitulélas Propalladia, a prothon, quod est primum; et Pallades, id est prima res Palladis... «. ${ }^{11}$ Es difícil saber con certeza lo que quiso decir con ello. El sintagma prime res Palladis puede ser traducido como 'los primeros intentos dedicados a Palas', significando que el autor, modesto, fue consciente de las imperfecciones de principiante de sus piezas (por eso intentos), ya que en la segunda parte de la frase hizo alusión a unas posibles obras ulteriores: »... a diferencia de las que secundariamente y con más maduro estudio podrían suceder.« Pero también puede tratarse de un homenaje por parte del autor al papa León X, que después de la época del pontificado inmoral de Alejandro VI, y de aquélla bélica bajo Julio III, consiguió finalmente a instaurar la época de la sabiduría. ${ }^{12}$ Naharro consideró la palabra Propalladia como plural del género neutro, aunque a continuación utilizara la forma del singular femenino, »esta mi Propalladia«, forma en la que también terminó por conservarse..$^{13}$

\footnotetext{
${ }^{9}$ Menéndez y Pelayo, Marcelino, Propaladia de Bartolomé de Torres Naharro, Librería de los bibliófilos (Libros de antaño, X), Madrid, 1900, vol. 2, p. LXXX. Cf. López Morales, Umberto, Tradición y creación en los origenes del teatro castellano, Ediciones Alcalá, Madrid, 1968, p. 24; Morales se distancia de ambas partes de la afirmación de Menéndez y Pelayo, opinando que no son convincientes, porque el autor no cita ejemplos suficientes que corroboren su hipotesis.

${ }^{10}$ Del lat. prooemium, introducción, prefacio. Tal vez Naharro optó por este término siguiendo el ejemplo de Juan de Mena (Prohemio ... al rey don Juan el Segundo), pero le llama también "este prefacio". Es interesante que el autor - antes de utilizar el término introíto - empleaba prohemio igualmente para los prólogos a sus comedias (Gillet, op. cit., vol. 3, p. 18).

${ }^{11}$ Bartolomé de Torres Naharro, Prohemio, en Gillet, op. cit., vol. 1, p. 141, líneas 25 y 26 . A continuación citaremos directamente de Gillet...

${ }^{12} \mathrm{Ibid}$., vol. 3, pp. 18-22.

${ }^{13} \mathrm{Ibid}$.
} 


\section{Teoría}

Sin embargo, Bartolomé de Torres Naharro no debe su fama a sus comedias; lo que le aseguró un lugar incontestable en la historia del teatro español - y con razón podríamos decir europeo - son sus reflexiones sobre el arte dramático resumidas en el Prohemio de la Propalladia. Estas consideraciones introductorias son indiscutiblemente los más antiguos preceptos dramáticos escritos en lengua española, y su originalidad hace del Prohemio uno de los más prestigiosos documentos de la teoría literaria renacentista en su conjunto. Los problemas teóricos expuestos por el autor son: la definición de la comedia, la división en cinco actos, el número de los personajes, el decoro, la división de las comedias en comedias a noticia y a fantasía, y partes de la comedia.

\section{La definición de la comedia}

Al principio parece que el tratado va a ser un interminable revisar del tradicionalismo conceptual, porque el preceptista se empeña - antes de exponer sus propias opiniones sobre la comedia - en poner de manifiesto su brillante conocimiento de autores clásicos y sus comentarios, citando varias definiciones antiguas:

Comedia, según los antiguos, es ceuilis priuateque fortune, sine periculo vite, comprehensio; a differentia de tragedia, que es heroice fortune in aduersis comprehensio. Y, según Tullio, comedia es immitiatio vite, speculum consuetudinis, imago veritatis. Y, según Acrón, poeta, ay seis géneros de comedias, scilicet: stataria, pretexta, tabernaria, palliata, togata, motoria; y quatro partes, scilicet: prothesis, ca/tá/strophe, prologus, epíthasis; y como Oratio quiere, cinco actos; y sobre todo que sea muy guardo el decoro etc. ${ }^{14}$

Joseph E. Gillet demuesta en su minuciosa edición científica de las obras de Naharro que éste no citó estos ejemplos clásicos directamente de los textos de sus autores, sino que se contentó con »copiar « los datos de la Familiaria Praenotamenta de Josse Badio. ${ }^{15}$

La abreviatura etc. con la que Naharro termina su exposición de citas clásicas algo injustificadamente sabia, muestra ya, sin embargo, su actitud hacia los clásicos y anuncia el tono en el que continúa su razonamiento: »Todo lo cual me paresce más largo de contar que necessario de oýr. « ${ }^{16}$ Cumplió con la tradición y pagó su deuda a las autoridades. En sus fórmulas sigue, de una manera indirecta, apoyándose en ellas, pero deja definitivamente de nombrarlas.

\footnotetext{
${ }^{14}$ Ibid., vol. 1, p. 142, líneas 37-45.

${ }^{15}$ Ibid., vol. 3, pp. 22-26. Josse Badio nació en 1462 en Bélgica (la última parte de su nombre procede de su ciudad natal Asc o Ascen cerca de Bruselas). Como muchos sabios renacentistas - fue también amigo de Erasmo - ennobleció su profesión de impresor, combinándola con el estudio humanístico. Fue excelente profesor de conocimientos antiguos, profesor de griego, primero en Lyon y luego en París. Escribió comentarios sobre numerosos clásicos, Boecio, Cicerón, Horacio, Juvenal, Lucano, Ovidio, Quintiliano, Séneca, Virgilio, tratados gramaticales, poesía y sátiras. Uno de sus textos más destacados son las citadas Praenotamenta, publicadas a manera de introducción en varias de sus ediciones de Terencio, la primera vez probablemente ya en 1500 , y con toda seguridad en 1502 en la edición lyonesa; en 1504 las revisó y volvió a imprimir varias veces. Están basadas, en parte, sobre el Commentum Terenti del gramático romano Elio Donato. Praenotamenta son un pequeño tratado de dramaturgia, que introdujo en la Europa del Renacimiento algunos de los primeros conocimientos sistemáticos sobre la crítica dramática, y cuyo valor sigue siendo subestimado.

${ }^{16}$ Ibid., vol. 1, p. 142 , líneas $45-47$.
} 
Continúa con »su propia« definición de la comedia:

Y digo ansí: que comedia no es otra cosa sino vn artificio ingenioso de notables y finalmente alegres acontecimientos, por personas disputado. $\ll^{17}$ Muy probablemente se basó otra vez en los escritos de Badio. Este, en el Cap. iii, escribe sobre el desenlace feliz: »/Comedia/ ... neque habet letum initium: sed potius finem ... Comedia autem in principio suspensa est et in medio turbulenta ... In fine autem omnes in gratiam redeunt ... Comedia contra principium ambiguum et satis tristem continet. finem autem letissimum. ${ }^{18}$

No obstante, aunque la concepción de la comedia de Naharro en su fondo corresponde a criterios clásicos, es obvio que toda su atención se centra en la manera, en la presentación divertida de los acontecimientos, dejando de lado las »cosas bajas y pequeñas « y el »bajo y homilde estilo«. Merece especial interés el sentido positivo de los adjetivos »ingenioso « y »notables «: Naharro ya no contrapone la comedia a la tragedia, sino que se dedica exclusivamente a ella para valorarla independientemente. Considerando este enfoque original del autor conviene destacar un hecho aparentemente insignificante: su precursor inmediato, Juan del Encina, había compuesto su Arte de la poesía castellana sin mencionar con una sola palabra el teatro, al cual deberá, sin embargo, toda su fama. Naharro, por el contrario, a pesar de que escribió también poesía, la consideró menos importante; la situó en segundo plano y habló sólo de la dramática:

La orden del libro, pues que ha de ser pasto espiritual, me paresció que se deuía ordenar a la vsança de los corporales pastos, conuiene a saber: dándoos por antepasto algunas cosillas breues, como son los Capítulos, Epístolas, etc.; y por principal cibo las cosas de mayor subjecto, como son las comedias; y por pospasto ansí mesmo algunas otras cosillas, como veréis. Quanto a lo principal, que son las comedias, pienso que deuo daros cuenta de lo que cerca d'ellas me paresce; no con presunción de maestro, mas solamente para seruiros con mi parescer, tanto que venga otro mejor. ${ }^{19}$

De una manera muy abierta y muy »española« se pronunció por el teatro, anticipando, indirectamente, el triunfo de la »comedia« en el Siglo de Oro.

\section{La división de la comedia en cinco actos (jornadas)}

Una de las partes más originales de la »teoría« de Naharro es su concepto del acto teatral. De acuerdo con la preceptiva Horaciana »neve minor neu sit quinto productior actu« acepta la partición en cinco actos, pero propone una interpretación peculiar: »La diuisión d'ella en cinco actos, no solamente me paresce buena, pero mucho necessaria; aunque yo les llamo jornadas, porque más me parescen descansaderos que otra cosa, de donde la comedia queda mejor entendida y rescitada. $\ll^{20}$ El latinismo acto como parte de la obra aparece aquí, tal vez, por primera vez en español. La palabra jornada (tanto como su diminutivo jornadeta que el autor utilizó en el Intoríto a la comedia Serafina) es un italianismo; sin embargo, Torres Naharro - según se deduce de su explicación - le concede un significado que no corresponde al de la palabra italiana giornata, y que tampoco es reconocido por la Academia Española. Para él, no es »camino de un día«, como dice

\footnotetext{
${ }^{17}$ Ibid., líneas 47-49.

${ }^{18}$ Ibid., vol. 3, pp. 22-26.

19 Ibid., vol. 1, p. 141, líneas 27-36.

${ }^{20} \mathrm{Ibid}$., p. 142, líneas 49-53.
} 
Nebrija, o »cosa de un día (Carvallo), sino concretamente el »descanso, reposo (al final del día)«; en esta acepción la encontramos en Cervantes (Don Quijote I, II): »Estaban acaso en la puerta dos mujeres mozas, destas que llaman del partido, las cuales iban a Sevilla con unos harrieros que en la venta aquella noche acertaron a hacer jornada. $\aleph^{21}$ Solamente si jornada se entiende como descanso, se puede explicar el argumento de Naharro »yo les llamo jornadas, porque más me parescen descansaderos que otra cosa «. Lo más probable es que descansaderos tenga aquí función de sustantivo y signifique »sitio o lugar donde se descansa o se puede descansar $\aleph^{22}$; en este caso tiene que referirse lógicamente no a los actos sino a los intervalos entre ellos, es decir, a los entreactos, que facilitan descanso tanto al público ( $»$ de donde la comedia queda mejor entendida «) como a los actores (»y rescitada «). Entonces, Torres Naharro habría pensado y dicho: "La división de la comedia en cinco actos no me parece solamente buena, sino muy necesaria; aunque yo les llamo jornadas (i. e. reposos, descansos), porque me parecen (cinco actos, cuatro entreactos) más descansaderos que otras disposiciones. « Gramáticalmente, descansaderos podría ser también participio en funcion adjetival, expresando entonces la cualidad del verbo descansar. En este caso habría que relacionarlo con el sustantivo precedente actos, o, mejor, con cinco actos, acentuando así el número exacto de actos. La interpretación cambiaría ahora en: »La división de la comedia en cinco actos no me parece solamente buena, sino muy necesaria; aunque yo les llamo jornadas, porque me parecen más descansaderos (i. e. »reposantes«) que otra cosa.« Sin embargo, esta segunda interpretación parece menos aceptable. ${ }^{23}$

El término novedoso jornadas no se extendió inmediatamente, prevaleció sólo hacia finales del siglo XVI, »resucitado « a la vez por Cristóbal de Virués en Valencia y Juan de la Cueva en Sevilla. El segundo autor hasta se atribuyó la invención - entre otras muchas, casi todas discutibles - de este término en su Ejemplar poético (1660): »A mí me culpan de que fuí el primero / que reyes y deidades dí al tablado, / de la comedia traspasando el fuero: / que el un acto de cinco le he quitado, / que reducí los actos en jornadas, cual vemos que es en nuestro tiempo usado. $\ll^{24}$ Aunque la ocurrencia pueda parecer sin importancia, es cierto que el verdadero introductor de ella fue Naharro, seguido por sus fieles discípulos Jaime de Huerte y Agustín Ortiz en sus comedias (Tesorina, Vidriana, Radiana). Las jornadas como partes de la comedia se mantuvieron también en el teatro barroco, pero su número, bajo la influencia de Lope, se redujo de cinco a tres.

\section{El número de los personajes}

En cuanto al número de los personajes Naharro ya no se ajusta a la rígida interpretación del precepto horaciano »nec quarta loqui persona laboret «, según la cual el número cuatro no se referiría únicamente a los interlocutores de un mismo diálogo, lo que parece racional, sino definiría el número máximo de los personajes escénicos. También Badio escribió aún: »Plures autem quam quattuor esse non possunt si quarta fuerit raris-

\footnotetext{
${ }^{21}$ Cervantes, Miguel de, Don Quijote de la Mancha I, Madrid, Cátedra, 1992, p. 107.

${ }^{22}$ Diccionario de la lengua española, Real Academia Española.

${ }^{23}$ Gillet, op. cit., vol. 3, pp. 22-26.

${ }^{24}$ Sánchez Escribano y Porqueras Mayo, op. cit., ed. 1972, p. 143.
} 
sime loquentur. Unde dicit Horatius in libro de poetica. $\aleph^{25}$ Mientras que Torres Naharro atenúa la norma y dice:

El número de las personas que se han de introduzir, es mi voto que no deuen ser tan pocas que parezca la fiesta sorda, ni tantas que engendren confusión. Aunque en nuestra Comedia Tinellaria se introduxeron passadas .XX. personas, porque el subjecto d'ella no quiso menos, el onesto número me paresce que sea de .VI. hasta .XII. personas. ${ }^{26}$

\section{El decoro}

Más provechosa que esta cuestión de carácter técnico es la ilustración del principio muy sensato y universal que habla del decorum, del comportamiento adecuado, de la dignidad de los actores, de su »actuación«, en la que tienen que respectar la justa mesura y conservar lo que es propio de las personas que representan:

El decoro en las comedias es como el gouernalle en la nao, el qual el buen cómico siempre deue traer ante los ojos. Es decoro vna justa y decente continuación de la materia, conuiene a saber: dando a cada uno lo suyo, euitar las cosas inproprias, vsar de todas las legítimas, de manera qu'el siruo no diga ni haga actos del señor, et e conuerso; y el lugar triste entristecello, y el alegre alegrallo, con toda la aduertentia y modo possibles, etc. ${ }^{27}$

\section{Comedia a noticia y comedia a fantasía}

La aportación más original de esta pequeña poética es, sin lugar a duda, la clara división de la comedia, válida no sólo para las comedias de nuestro autor, sino para cada teatro en cada época, puesto que contiene dos orientaciones claves relacionadas con la cuestión perenne de la mímesis y del realismo. Naharro apunta:

Quanto a los géneros de comedias, a mí paresce que bastarían dos para nuestra lengua castellana: comedia a noticia y comedia a fantasía. A noticia s'entiende de cosa nota y vista en realidad de verdad, como son Soldadesca y Tinellaria; a fantasía, de cosa fantástiga o fingida, que tenga color de verdad aunque no lo sea, como son Seraphina, Ymenea, etc. ${ }^{28}$

Ambas palabras, noticia y fantasía, son españolas, pero el idioma a fantasia proviene del italiano (di invenzione, seguendo l'imaginazione), normalmente utilizado con el pronombre intercalado (a loro fantasia). La connotación dominante en la definición de Naharro es probablemente musical, tal como se estableció en la Europa del siglo XVI. Designa las imaginaciones musicales en ciertas composiciones instrumentales basadas generalmente en un tema vocal, como p. ej. ricercario, tiento, motete, glosado, y, especialmente, fantasia - composición instrumental cerca de la improvisación. A noticia es probablemente un hallazgo naharresco, invención italianizante según el modelo de a fantasía. Esta división original del autor y su explicación correspondiente podrían ser entonces parafraseadas así: comedia a noticia, es decir, comedia sobre las cosas que han acaecido en realidad, y comedia a fantasía, comedia sobre las cosas imaginativas. Apoyándonos en la terminología moderna diríamos comedia realista y comedia idealista.

\footnotetext{
${ }^{25}$ Gillet, op. cit., vol. 3, pp. 22-26.

${ }^{26}$ Ibid., vol. 1, p. 142, líneas 53-59.

${ }^{27}$ Ibid., líneas 59-66.

${ }^{28}$ Ibid., líneas 67-73.
} 
Torres Naharro se apoyó, en un primer momento, en la teoría heredada de la antigüedad, desarrollando a partir de ella la división en obras reflejadas de la realidad, es decir, »miméticas«, y otras, que son resultado del ingenio del autor, pero que aún así tienen que corresponder a la realidad (»que tengan color de verdad aunque no lo sea«), es decir, »menos miméticas «, pero verídicas. Tal distinción artística según el grado del mimetismo valora más lo puramente teatral y viene a oponerse a los habituales criterios clasicistas que distinguían las comedias por motivos externos, como la edad del protagonista o la localización y el tiempo de la acción (stataria, praetexta, tabernaria, palliata, togata, etc.). ${ }^{29}$

\section{Introíto y argumento}

En la división interior de la comedia Torres Naharro sigue liberándose de los modelos clásicos citados anteriormente y propone, en vez de cuatro partes que distingue Acrón, sólo dos: »Partes de la comedia, ansí mesmo bastarían dos, scilicet: introito y argumento. Y si más os paresciese que deuan ser, ansí de lo vno como de lo otro, licentia se tienen para quitar y poner los discretos. ${ }^{30} \mathrm{La}$ formulación no parece del todo clara. El introito (prólogo en las comedias clásicas y autores italianos del siglo XVI) fue una introducción en la vivencia dramática, la presentación de los personajes, algunas veces con elementos de la apología del autor, lo todo puesto en la boca de un pastor y recitado en tono desenfrenado para atraer la atención del auditorio. Incluía también el resumen de la acción que se desarrollaría a continuación, el título, número de actos y, para terminar, la promesa de proporcionarle diversión al público y la incitación a seguir atentamente la función. En cambio, el argumento fue el desarrollo mismo de la fábula, es decir, la representación. Pero en la repartición de Naharro el término argumento no puede ser entendido como la parte central de la acción, puesto que él mismo lo utilizó para designar la segunda parte del introito, es decir, para una exposición condensada de la acción. Todas sus comedias empiezan con una introducción, bajo un único título Introyto y argumento. Así que introíto es en realidad sólo la primera parte, y argumento su segunda parte, entonces una parte integral del intorito. ${ }^{31}$ Tal vez podamos suponer que el autor quiso poner »dos partes«, pensando con ello en el prólogo y la representación, pero que en un momento interrumpió su razonamiento y saltó a la división del prólogo, olvidándose de su intención originaria. ${ }^{32}$

Es significativa la observación del preceptista sobre el »quitar y poner« de las partes de la obra. Aunque algo moderada por la inclusión del concepto típicamente clásico de la mesura (»los discretos «), con este »llamamiento « a los creadores Naharro vuelve a mostrar su actitud de renovador sereno y lleno de confianza en sí mismo.

\footnotetext{
${ }^{29}$ Pérez Priego, op. cit. p. 53.

${ }^{30}$ Gillet, op. cit., vol. 1, p. 143, líneas 73-76.

${ }^{31}$ Pérez Priego, op. cit., p. 53.

${ }^{32}$ Gillet, op. cit., vol. 3, p. 26-28.
} 


\section{Entre la teoría y la práctica}

El concepto de la comedia de Torres Naharro es esencialmente clásico: son clásicos los principios dramáticos que presenta en el Prohemio, las autoridades que alega, la división en cinco actos y el uso del introíto. No obstante, la fuerza motriz de su teoría dramática es el deseo de superar estas convenciones más o menos clasicistas, restablecidas en el Renacimiento por los escritores italianos. De ahí que, al teorizar, Naharro no adopte ciegamente la tradición sino que la adapte, en el espíritu humanista de la época, a sus propias ideas, hasta rechazarla deliberadamente algunas veces, contraponiendo a ciertos modelos antiguos sus propias definiciones y asumiendo con ello la responsabilidad de la renovación. Otra característica no menos notoria de su exposición teórica es que, contrariamente a la tendencia a la codificación del teatro, propia de aquella época, Naharro relativiza la norma, concediendo explícitamente una cierta libertad artística a los escritores. Esta actitud nada servil frente a la tradición clásica y el espíritu tolerante no distinguen sólo a Naharro, sino a todos los creadores españoles renacentistas, que, justamente con ello, han contribuido considerablemente a la génesis del teatro europeo contemporáneo. Asimismo, Naharro elude estratégicamente la confrontación con la tragedia; destaca decididamente la comedia, la clasifica y define de manera original, entrando así en la corriente creadora que desembocará en la comedia nueva cuyo nacimiento se atribuye demasiadas veces y de manera general y exclusiva a Lope de Vega.

Las comedias de Torres Naharro, por su parte, no hacen sino continuar la tradición salmantina de Juan del Encina y sus imitadores; aunque el autor asentado en Roma las enriqueció con una mezcla de influencias latinas e italianas, no alcanzan la calidad de su teoría y tampoco sobresalen de las creaciones de sus contemporáneos. Los rasgos más significativos que las hacen distinguir son, tal vez, sus intrigas originales, la mezcla de diferentes lenguas y dialectos, el uso de proverbios y dichos populares y, sobre todo, sus diálogos llenos de virtuosidad y agudeza.

Sin embargo, la ingeniosidad y la fuerza liberadora del tratadista que emanan de su teoría contaminan también al dramaturgo: aunque el autor traslada fielmente la mayoría de los criterios de su poética a sus comedias, acaba por desobedecer, sea conciente sea inconscientemente, algunos de ellos, o, por lo menos, acomodarlos a sus necesidades.

Así, por ejemplo, el número de personajes, definido de manera ya suficientemente libre »de seis hasta doce«, se ve considerablemente sobrepasado en Tinellaria. El autor se dio cuenta de esta trasgresión, pero la justificó ya en el mismo Prohemio, diciendo simplemente que »el subjecto d'ella no quiso menos «.

Hemos explicado la ambigüedad respecto a la denominación del introíto y argumento. Pero más que esta aporía terminológica parece importante su contenido. El introíto de Naharro tiene valor en sí mismo, independientemente de la obra de la que es preludio y cuyo argumento resume. El villano que en el monólogo cuenta, en bajo estilo pero con una fuerza cómica, sus raíces, sus quehaceres y aventuras libertinas con las jóvenes de su pueblo, en las comedias de Naharro no dice sólo groserías y bobadas, sino que a menudo insinúa también los pensamientos críticos del autor sobre las injusticias sociales de su tiempo. Uno de los ejemplos más significativos se encuentra en la Soldadesca, donde el campesino en cuanto representante de la clase explotada protesta contra la aristocracia tanto eclesiástica como civil: 


Por probar,
ora os quiero pregunar:
¿Quién duerme más satisfecho?
¿Yo de noche en un pajar,
ó el Papa en su rico lecho?
(...)
Yo villano,
biuo más tiempo, y más sano
alegre todos mis días,
y biuo como christiano,
por aquestas manos mías.
Vos, señores,
biuís en muchos dolores
y sois ricos de más penas,
y coméis de los sudores
de pobres manos agenas.

Sin duda, los desacuerdos más interesantes entre la teoría y la práctica dramáticas naharrescas proceden de la clasificación de la comedia en comedia a noticia y a fantasia. Los ejemplos de ambos géneros, que el autor escoge entre sus obras para justificar con ellos la nueva denominación, sirven, por un lado, a aclarar esta clasificación, y, por el otro, a suscitar dudas sobre la firmeza del autor a la hora de cumplir la »regla«.

Las comedias a noticia son casi un ejemplo escolar de la aplicación de la teoría en la práctica, puesto que el dramaturgo observa perfectamente el criterio de la realidad en el sentido más estricto de la palabra. La Soldadesca y la Tinellaria son, en efecto, una especie de cuadros de género. Con asombrosa minuciosidad el escritor grabó »del natural « lo que cotidianamente veía: en la primera, como el título lo indica, las costumbres en la milicia romana, y, en la segunda, las escenas de la vida en los tinelos de las autoridades eclesiásticas. En ambas aparece toda una galería de personajes, que invaden el escenario, hablando en diversas lenguas, gesticulando todos a la vez, bebiendo, comiendo, riñendo y divirtiéndose groseramente.

La Soldadesca carece de verdadera acción dramática. Está situada en Roma, en la época tumultuosa del pontífice Julio II. Este necesita un nuevo ejército de quinientos peones. El capitán que tiene el encargo de formarlo encuentra a un soldado español, Guzmán, y le ofrece el grado de sota-capitán. Comienzan los preparativos, se reclutan soldados, entre ellos un tambor, un fraile apóstata, un labrador, se ajustan los sueldos y puesto que los »compañeros « hablan en diferentes idiomas y dialectos - no llegan siempre a entenderse y surgen equivocaciones continuas entre unos y otros. Guzmán, con ayuda de un compatriota suyo se propone hurtarle las pagas al capitán y desertar, y al final, después de una sucesión de peripecias, todos marchan en ordenanza cantando un villancico. Apoyado en este débil hilo conductor, Torres Naharro despliega una serie de escenas costumbristas dialogizadas casi autónomas, en las que pinta los desafueros y la atmósfera degradada en los ejércitos mercenarios. Pero es justamente este carácter episódico el que hace la comedia más identificable con la realidad de su momento. En el

${ }^{33}$ Ibid., vol. 2, pp. 142-143, Introíto, vv. 55-59 y 75-84. 
texto hay incluso algunas referencias a lugares y acontecimientos reales. Por ejemplo, cuando Guzmán bravea delante del capitán y subraya sus facultades militares enumerando sus proezas pasadas:

$\begin{array}{cl}\text { Capitán: } & \text { Pues, hermano, } \\ & \text { ya sé que por vuestra mano } \\ & \text { cresce la fama española. } \\ \text { Guzmán: } & \text { ¿Vístesme en Garellano? } \\ \text { Capitán: Y } \text { aun os ui en Chirinola. } \\ \text { Guzmán: Yo he plazer } \\ \text { que me queréis conoscer } \\ \text { sin auérselo seruido. } \\ \text { Pues, más auéis de saber: } \\ \text { que he diez vezes combatido, } \\ \text { y en Bugía } \\ \text { yo tuue una compañía, } \\ \text { la mejor de mi quartel, } \\ \text { y en Trípol de Beruería } \\ \text { pudiera ser coronel. } .^{34}\end{array}$

Debido al esfuerzo inhumano exigido a los combatientes, al sufrimiento y a las enormes pérdidas en ambos campos, las batallas franco-españolas de Cerignola ( $28 \mathrm{de}$ abril de 1503) y la de Carigliano (28 de diciembre del mismo año) resonaron durante largo tiempo en la Europa de aquel entonces. Las ciudades norteafricanas Bugía y Trípoli fueron conquistadas por los españoles en el año 1510 (la primera el 6 de enero y la segunda el 31 de julio). ${ }^{35}$

Torres Naharro, entonces, no ha tejido ninguna situación imaginaria, no ha introducido ningún elemento de artificio y hasta ha nivelado la importancia dramática de los personajes. En su sinceridad deja expresarse la naturaleza más humana de aquella gente, sin ningún tipo de sublimaciones. Guzmán no es una ilustración grotesca del mercenario fanfarrón, sino un soldado de verdad, curtido en campañas sangrientas; a este soldado Naharro lo ha pintado tal como fue, con una objetividad tan palpable que la Soldadesca - escrita para arrancar carcajadas a sus contemporáneos - conserva hoy el valor de un documento histórico.

El ambiente de la Tinellaria es aún más soez y su descripción aún más naturalista. Los cinco actos de esta comedia no son sino una interminable juerga desenfrenada en las cocinas de un cardenal romano durante los preparativos de un banquete. Los personajes aparecen en sus más bajas condiciones, el hambre, la envidia, la lujuria, la pereza etc. El principal atractivo de esta pieza son los diálogos - una mezcla babilónica de hablas, puesto que los sirvientes han acudido de todas partes y cada uno habla en su idioma: en castellano, catalán, italiano, francés, portugués y latín macarrónico. La autenticidad de las descripciones de Naharro no deja lugar a duda, considerando que en aquellos años estuvo él mismo al servicio de dignatarios eclesiásticos y tuvo entonces la oportunidad de conocer en detalle la vida cotidiana »entre bastidores«.

${ }^{34}$ lbid., p. 151, Jornada I, vv. 150-164.

${ }^{35}$ Ibid., vol. 3, pp. 404-406. 
Las discrepancias entre los textos teóricos y dramáticos de Naharro surgen sólo en sus comedias a fantasia: en la Serafina y la Himenea y sobre todo en la Aquilana que el autor no menciona en Prohemio, por no haberla escrito todavía cuando se publicó la primera edición de la Propalladia. Dichas comedias difieren considerablemente de las anteriormente mencionadas. Todas observan la primera parte de la norma »a fantasía«: representan una acción imaginaria (casi siempre de carácter amoroso), están llenas de misterios y escenas nocturnas, novelescas. En principio, obedecen también la segunda mitad de la definición (»que tenga color de verdad aunque no lo sea«), sin embargo, introducen también aspectos que difícilmente cabrían en un contexto rigurosamente verídico.

El tema de la Serafina es la bigamia: Floristán, un joven presumido de Valencia, se casa en Roma con Orfea, dejando abandonada en su ciudad natal a Serafina, a quien había conquistado bajo palabra de casamiento. Serafina va en su busca y da con él. Este siente renacer su antiguo amor por ella, pero, para evitar el pecado de bigamia, opta por matar a la esposa italiana. Antes de proceder al acto acude en consulta al fraile Teodoro, quien en principio se muestra conforme, pero advierte que la víctima no debe morir sin confesión. Por suerte, todo termina sin derrame de sangre, puesto que, de improvisto, aparece un rico hermano de Floristán, Policiano, el ex-enamorado de Orfea. El fraile descasa a Orfea, de modo que ésta puede casarse en segundas nupcias con Policiano, y Serafina, por su lado, le perdona todo a su pretendiente.

En la comedia hay algunos elementos que exceden a la verosimilitud prescrita en la definición del preceptista. En primer lugar, el monólogo de Floristán delante de Teodoro, en el que el charlatán explica su razonamiento: sabe que es él mismo el que más merece la muerte, pero para evitar una mayor desgracia, no se va a matar. De hacerlo, Serafina se desesperaría y Orfea moriría de pena. Le parece más sensato quitarle la vida a Orfea, procurando que Serafina lo compruebe con sus propios ojos. De este modo, con una sóla muerte impedirá una triple tragedia. Orfea morirá como buena cristiana, en tanto que él ya tendrá tiempo en toda su vida para arrepentirse:

Floristán: (...)
y es aquesta la verdad,
y por ella moriré.
Mas yo no dexo de ver
que me deuría matar;
y por más daño escusar
no lo quiero ora hazer,
sino qu' es mui menester
que yo mate luego a Orphea
do Seraphina lo vea,
porque lo pueda creer.
Que yo bien me mataría,
pues toda razón me inclina,
pero sé de Seraphina
que se desesperaría.
Y Orphea, pues ¿qué haría
quando mi muerte supiesse?


Que creo que no pudiesse

sostener la vida vn día.

Pues, hablando acá entre nos,

a Orphea cabe la suerte,

porque con su sola muerte

s' escusarán otras dos.

De modo que, padre, vos,

si llamármela queréis,

a mí, merced me haréis,

y también seruicio a Dios.

(...)

Porque si yo la matare,

morirá christianamente;

yo moriré penitente

quando mi suerte llegare. ${ }^{36}$

Juzgando la pieza por las impertinentes exigencias clacisistas de mímesis y decoro, el carácter de Floristán parece abominable. Así lo vio también Leandro Fernández Moratín. ${ }^{37}$ Sin embargo, hay que tomarla más bien por su lado bufonesco, como una mera caricatura. Es lo que propone Menéndez y Pelayo, según quien lo cómico de la situación nace del »contraste entre los enfáticos lugares comunes que Floristán va ensartando en las abominables acciones y que le lleva su torpe egoísmo, entre la grandeza de un ideal ético y religioso que no comprende, y la ruindad de su alma depravada y mezquina, que quiere encubrir su miseria con palabras sonoras. $\aleph^{38} \mathrm{La}$ caricatura del personaje se apoya en »la mezcla de barbarie y de superstición que hay en él, la misma inconsecuencia de sus actos y palabras, la alta idea de su persona, la cínica franqueza con que plantea y resuelve el problema de su vida, la candorosa egolatría de que hace alarde y el extraño sentimentalismo que a deshora se apodera de él. $\aleph^{39} \mathrm{La}$ inmoralidad de Floristán es tan cándida, los móviles de sus acciones tan extraños y absurdos, las resoluciones que toma tan ridículamente atroces, que el conflicto dramático se resuelve en un episodio grotesco.

Otra escena en la Serafina tiende a lo inverosímil: la llegada repentina del rico hermano de Floristán. Policiano aparece como caído de las nubes y, como una especie de deus ex machina, soluciona la situación embarazosa y evita el trágico desenlace que se anunciaba, llevando felizmente la comedia hasta »finalmente alegres acontecimientos«.

Un vaivén parecido entre lo cómico y lo trágico se repite en las dos mejores comedias, la Himenea y la Aquilana. En la Himenea, indudablemente la más delicada y más »caballeresca «, el autor muestra su talento como pintor de costumbres urbanas. Aparte de la mesura - la observación del decoro - y la composición sobria, sorprende en ella la cortesana gentileza de los personajes, su expresión poética y no afectada de los sentimientos, cualidades que el lector no esperaría de un autor que de una manera tan dra-

\footnotetext{
${ }^{36}$ Ibid., vol. 2, p. 39, Jornada III, vv. 31-52 y 61-64.

${ }^{37}$ Fernández Moratín, Leandro, Tesoro del teatro español, desde su origen hasta nuestros días, t. I, Librería europea de Baudry, París, 1838 , p. 64.

${ }^{38}$ Menéndez y Pelayo, op. cit., p. CXXIV.

${ }^{39}$ Ibid.
} 
coniana y realista presentó a los toscos personajes en la Soldadesca y la Tinellaria. La acción argumental en la Himenea se desarrolla alrededor de un imaginario caso de amores: Himeneo se enamora de Febea y tras largas declaraciones y serenatas consigue que le admita en su casa la noche siguiente. Pero en la cita concertada les sorprende el Marqués, hermano de Febea, que - para salvar el honor familiar - se dispone a dar muerte a su hermana, aunque ésta proclama su inocencia. Himeneo huye, pero regresa a tiempo y acaba por casarse con Febea. Otra vez, el comediógrafo evadió de forma imprevista e inmotivada el final trágico.

Esta comedia tiene valor de antecedente en el teatro español: el tema del honor de la doncella, del honor familiar y de la venganza, anuncia la comedia barroca de capa y espada que alcanzó su apogeo con Calderón. Y es justamente desde el punto de vista del honor que sorprende y desconcierta la escena en la que Himeneo se escapa y abandona a su dama en peligro de muerte, ya que la fuga, y más en circunstancias como éstas, no corresponde a ningún código de honor. Una de las posibles explicaciones de este acto que parece inverosímil es la necesidad técnica que tenía Naharro de sacar a Himeneo de la escena para que tuviera lugar el discurso »melibeano« de Febea. Al fin y al cabo, Himeneo regresa con sus criados - que también han huido momentos antes - no a batirse, sino a proponer las bodas pacíficamente. Es decir, que si Naharro ha roto con la realidad, lo ha hecho intencionadamente. Sin embargo, según algunos autores no hay razón para considerar la huida de los criados, presos de pánico mientras vigilaban delante de la casa, como un suceso realista, mientras que la huida de Himeneo nos parezca una ruptura con la »verosimilitud« del argumento, de motivación psicológica que se trata de dar a la pieza. ${ }^{40}$

Si la Himenea se sitúa entre las comedias de capa y espada, la Aquilana es casi una comedia heroica con infantas enamoradizas y príncipes disfrazados a estilo de Lope. En esta comedia, la más extensa de Torres Naharro, predominan largos parlamentos y monólogos de los personajes y excursos episódicos. La intriga gira en torno a los amores del caballero Aquilano y la dama Felicina, hija del rey Bermudo. Tras una de sus visitas nocturnas, Aquilano cae de un manzano; lo descubren los hortelanos Dandario y Galterio y lo llevan delante del rey. Los médicos de palacio diagnostican su mal de amores y el rey ordena su muerte. En el último momento, el criado Faceto revela que su amo es hijo del rey de Hungría, lo que al punto hace que Bermudo renuncie a la venganza y perdone al amante. Pero Felicina, en tanto, ha salido al jardín y trata de ahorcarse desesperada. Lo impide su criada Dileta que le trae la buena noticia; acuden también el rey y los demás personajes, y todo concluye con el abrazo de los futuros esposos. Se trata, por tanto, de una comedia novelesca, con una trama bien tejida y con el conocido recurso del reconocimiento de personalidad al final de la intriga.

Este recurso, precisamente, provocó la indignación de Moratín, que juzgó la solución »inverosímil y forzada«: »Faltó el autor al respeto que se le debe a la Historia, suponiendo un príncipe Aquilano de Hungría yerno de un rey Bermudo de León y heredero de su corona: las libertades poéticas no permiten tanto. « ${ }^{41}$ Pero hay que tener en

\footnotetext{
${ }^{40}$ López Morales, Umberto, Comedias de Bartolomé de Torres Naharro, Taurus, Madrid, 1986, p. 74, nota.
} 
cuenta que no se trata de un drama histórico sino de una comedia »romántica a fantasía, en la que dicho procedimiento ya no es inadmisible.

La plausibilidad de la comedia es más discutible por la perseverancia aparentemente incomprensible de Aquilano en encubrir su identidad. Al principio su motivación parece lógica: quiere disimular sus raíces por ver si logra el amor de Felicina sólo con méritos personales y no por su sangre real. Pero luego, cuando el rey Bermudo parece decidido a hacerlo matar, el joven se obstina en seguir callando, a pesar de que todo le indica que nada conseguirá con su silencio. Tal comportamiento no puede ser sino respuesta de un amante inexorablemente hundido en su pasión y no correspondido por su amada. Porque es cierto que Aquilano no ha podido arrancar de la infanta una palabra de amor, y sí muchas de reproche, que él toma por sinceras y no por lo que son - producto de la coquetería de Felicina, y, por lo tanto, está decidido a recibir la muerte tan ufano como Macías, del que habla en uno de sus monólogos (v. 533) y al que califica de 'glorioso'. ${ }^{42}$ Es lo que confiere un pronunciado aspecto romántico al personaje. Con él, Naharro ha plantado en forma casi definitiva el prototipo del galán que - junto a su dama, el gracioso y la criada - presentará el pilar de gran parte del teatro español del Siglo de Oro.

A pesar de que en su tratado teórico Torres Naharro siguió los rígidos principios dramáticos clasicistas (imitación de la vida, espejo de las costumbres, imagen de la verdad), vemos que en sus comedias a fantasía, en algunos momentos, los desobedeció o por lo menos aflojó, porque al escribir, aparentemente, se dejó llevar más por el deseo de divertir al auditorio que por la obligación de cumplir con el verismo.

De manera original, el hispanista francés Marcel Bataillon ${ }^{43}$ relacionó las »infracciones « de Bartolomé de Torres Naharro - que los críticos literarios anteriores han entendido como »clara tendencia del poeta a la parodia « $\left(\right.$ Gillet $\left.^{44}\right)$, las acusaron con resolución (Moratín), o tacharon de »puros disparates« y »bufonadas« (Menéndez y Pelayo ${ }^{45}$ ) - con el término »esperpentización«. En el carácter burlesco, lúdico de las comedias y en la facilidad con la que crean y disipan la amenaza de la tragedia, más que trasgresión de leyes verídicas, reconoce un posible »deformar « ocasional y deliberado, tal como cuatrocientos años más tarde practicó sistemáticamente Ramón de Valle Inclán en sus esperpentos. Desde luego, esta alusión de Bataillon no significa que el dramaturgo prerrenacentista escribiera esperpentos, ya que el género fue inventado y definido por don Ramón; pero es precisamente por ello interesante señalar algunos componentes y recursos en la obra de Naharro que construyen la estética valleinclániana, es decir, lo esperpéntico como categoría artística, mucho más importante que el propio género. Estas características son una constante en las letras españolas, identificadas desde los diálogos medievales, las primeras églogas, pasando por el Libro de buen amor, la Celestina y los géneros menores, como el sainete y el entremés. En las obras de Naharro, aparte de lo burlesco y de la frontera indecisa entre la solemnidad trágica y la comicidad, mencionados por Bataillon, se

\footnotetext{
${ }^{41}$ Fernández Moratín, op. cit., p. 69.

${ }^{42}$ López Morales, op. cit., p. 77.

${ }^{43}$ Bataillon, Marcel, "Le Torres Naharro de Joseph E. Gillet", en: Romance Philology, XXI, 2, nov. 1967, pp. 143-170.

${ }^{44}$ Gillet, op. cit., vol. 3, p. 807.

${ }^{45}$ Menéndez y Pelayo, op. cit., p. CXX.
} 
inscriben en la misma línea esperpéntica la deformación a lo grotesco, la presentación de los personajes como si fueran títeres, elementos de absurdidad, el distanciamiento afectivo, la teatralería, la crítica social y la ausencia de la moralización.

Pero a pesar de los »detalles esperpénticos « citados, la obra de Naharro es esencialmente incompatible con el concepto del esperpento. Aunque es muy probable que también Naharro haya percibido las absurdidades de la época y de la sociedad en que vivía, se propuso, en cuanto dramaturgo renacentista - conforme a la metáfora tradicional del espejo que capta la apariencia de las cosas y las refleja - a imitar, a representar el mundo tal como es, si necesario, también deformado; mientas tanto, en Valle-Inclán esta metáfora adquiere otro significado. El dramaturgo de los principios del siglo XX escogió como punto de partida de su visión de la realidad (absurda) el espejo cóncavo. Este capta las cosas de modo que resultan distorsionadas. Entonces, la deformación pierde su deformidad, porque aquí la realidad absurda se ve exactamente como tal, se amolda matemáticamente a su imagen absurda reflejada en él ${ }^{46}$ Los dramas de Valle-Inclán no crean la ilusión de una realidad, sino que establecen la realidad de una ilusión. Ya no se trata del realismo crítico sino del realismo esperpéntico. Evidentemente, Torres Naharro en su visión no llegó a tanto, por lo que sería inadmisible sobreinterpretar sus comedias y asociarlas con una actitud artística tan lúcidamente elaborada, actitud que logra integrar las leyes estilísticas y el contenido moral, sociológico, histórico, estético y social, que virtió en sus creaciones Ramón de Valle-Inclán.

\section{Bibliografia}

Aristoteles, Poetika, Cankarjeva založba, Ljubljana, 1982.

Bataillon, Marcel, »Le Torres Naharro de Joseph E. Gillet«, en: Romance Philology, XXI, 2, nov. 1967, pp. 143-170.

Cañete, Manuel, Propaladia de Bartolomé de Torres Naharro, Librería de los bibliófilos (Libros de antaño, IX), Madrid, 1880 (vol. 1), 1990 (vol. 2).

Cardona, Rodolfo, y Zahareas, Anthony N., Visión del esperpento: teoría y práctica en los esperpentos de Valle-Inclan, Editorial Castalia, Madrid, 1970.

Díez Borque, José M., Los géneros dramáticos en el siglo XVI: El teatro hasta Lope de Vega, Taurus, Madrid, 1987.

Fernández Moratín, Leandro, Tesoro del teatro español, desde su orígen hasta nuestros días, t. I, Librería europea de Baudry, París, 1838.

Fuente, R. de la (ed.), Hermenegildo, Alfredo, Historia de la literatura española, El Teatro del siglo XVI, Ediciones Jucar, Madrid, 1994.

Gillet, Joseph E. (ed.), Propalladia and other works of Bartolomé de Torres Nahharro, Bryn Mawr-Philadelphia, University of Pensylvania, 1943-1951, 3 vol.

Horac, »Pismo o pesništvu (De arte poetica epistula ad Pisones)«, O pesništvu, ed. A. Sovrè y K. Gantar, Mladinska knjiga, Ljubljana, 1963.

\footnotetext{
${ }^{46}$ Cardona, Rodolfo, y Zahareas, Antony N., Visión del esperpento: teoría y práctica en los esperpentos de ValleInclán, Editorial Castalia, Madrid, 1970, p. 37.
} 
Huerta Calvo, Javier, El teatro medieval y renacentista, Playor, Madrid, 1984.

López Morales, Humberto, Comedias de Bartolomé de Torres Naharro, Taurus, Madrid, 1986.

- Tradición y creación en los orígenes del teatro castellano, Ediciones Alcalá, Madrid, 1968.

Marbán, Edilberto, El teatro español medieval y del Renacimiento, Las Américas, Madrid, Nueva York, 1971.

Oliva, César, Antecedentes estéticos del esperpento, Cuadernos de la Cétedra de Teatro de la Universidad de Murcia, Ediciones 23-27, Murcia, 1978.

Pérez Priego, Miguel Angel, Estudios sobre teatro del Renacimiento, Universidad Nacional de Educación a Distancia, Madrid, 1998.

Rojas, Fernando de, La Celestina, Cátedra, Madrid, 2000.

Ruiz Ramón, Francisco, Historia del Teatro Español (Desde sus orígenes hasta 1900), Cátedra, Madrid, 1992.

Sainz Rodríguez, Pedro, Historia de la Crítica literaria en España, Taurus Humanidades, Madrid, 1989.

Sánchez Escribano, Federico, y Porqueras Mayo, Alberto, Preceptiva dramática española del Renacimiento al Barroco, Gredos, Madrid, 1965 y la 2. ed. compl., 1972.

Strosetzki, Christoph, Teatro español del Siglo de Oro, Vervuert//beroamericana, Frankfurt am Main/Madrid, 1998.

Torres de Naharro, Bartolomé /de/, Propalladia (Nápoles, 1517), facsímile Madrid, 1936.

Weinberg, Bernard, A History of literary criticism in the Italian Renaissance, 2 vols., University of Chicago Press, Chicago, 1961.

\section{BARTOLOMÉ DE TORRES NAHARRO MED DRAMSKO TEORIJO IN PRAKSO}

Članek predstavlja enega pomembnejših dokumentov renesančne dramske teorije, Prohemio (Predgovor), ki ga je k svojim zbranim delom napisal španski komediograf Bartolomé de Torres Naharro. Njegova razprava prinaša izvirno definicijo komedije in razmišljanja o njeni zgradbi, posebej zanimiva pa je delitev glede na stopnjo mimetičnosti (a noticia in a fantasía). Drugi del študije izpostavlja primere avtorjevega nedoslednega spoštovanja pravil, ki jih je sam zasnoval. 